\title{
CURRENT RESEARCH METHODOLOGIES FOR REDISCOVERING FORGOTTEN COMPOSERS: USING COMMERCIAL GENEALOGY AND NEWSPAPER DATABASES AND OTHER ONLINE ARCHIVES
}

NICO SCHÜLER

\begin{abstract}
This paper describes the reconstruction of the life and work of African-American composer Jacob J. Sawyer and the correction of one biographical aspect of African-American composer Edmond Dédé with the help of commercial genealogy and newspaper databases as well as online collections of music scores.
\end{abstract}

Key Words: Jacob J. Sawyer; Edmond Dédé; $19^{\text {th }}$ century; African-American composers; minstrelsy; piano music; newspaper databases; genealogical research.

\section{Introduction}

I pursued my first extensive archival research project in Brno (Czech Republic) in 1995-1996. It was on the musical life of the Germans in Brno in the 1920s, and my main sources were (a) newspapers of the time, which I accessed in hard copy in libraries, and (b) biographical music dictionaries, especially those published during the 1920s, which contained entries on composers and musicians of the time. The project was very time consuming. Today, 20 years later, many such sources (newspapers and dictionaries) are available online in digital format, but searching in them is still very challenging. This paper discusses some experiences with searching in online databases and archives to rediscover forgotten composers. Specifically, I report on using commercial genealogy databases in the rediscovery of Jacob J. Sawyer (1856-1885) and Edmond Dédé (1827-1901). ${ }^{1}$

\section{Academic vs. Commercial Newspaper Databases}

For the composers discussed below, I was looking for newspaper databases, as traditional research databases did not provide sufficient information. My goal was to find newspaper articles on the composers, so I could reconstruct their

1 This paper presents revised and expanded research originally published as Schüler, 2015 and Schüler, 2016. 
biographies. I found the following "academic" newspaper databases:

19th Century US Newspapers (Gale-Cengage Learning)

Chicago Tribune (Historical from ProQuest)

Dallas Morning News (Historical Archive from NewsBank, Inc.)

Los Angeles Times (Historical from ProQuest)

New York Times (Historical from ProQuest)

Wall Street Journal (Historical from ProQuest)

Washington Post (Historical from ProQuest)

Most of these databases contained very specific newspapers as indicated by their titles, none of which were published in cities where the two composers I consider had lived or worked. Only the 19th Century US Newspapers database had a more general focus that seemed useful for my research. Reading about this 19th Century US Newspapers database, I learned that it contains about 500 urban and regional newspapers, special-interest publications, and illustrated papers that were published throughout the United States during the 19th century; it contains about 1.8 million pages. Searching in this database, however, resulted in very few useful documents for this project.

After extensively searching in the world wide web, I came across several "commercial" genealogy databases and "commercial" newspaper databases:

http://www.ancestry.com

http://www.genealogybank.com

http://newspaperarchive.com

http://newspapers.com

These commercial genealogy databases have many more records than academic databases. For example, http://www.genealogybank.com contains more than 7,000 different newspapers with more than 1 billion records; it has an annual membership fee of about $\$ 70$. The commercial newspaper database http:// newspapers.com contains more than 4,400 newspapers from the 1700s through today and more than 255 million pages; millions of additional pages are added every month; its annual membership fee ("access everything") is $\$ 150$.

We can easily see that the commercial databases contain many more documents than the academic databases, which makes the commercial databases much more attractive for academic research. The following two sections provide examples of how these commercial databases provide valuable information for the rediscovery of these composers. 


\section{The Forgotten Composer Jacob J. Sawyer}

For James M. Trotter's famous book Music and Some Highly Musical People (Trotter, 1880), only 13 pieces of music were selected for inclusion; one of these pieces was by African-American composer Jacob J. Sawyer ${ }^{2}$. The inclusion of one of his compositions in Trotter's book marks Sawyer as an exemplary and well-known composer, despite his young age at the time of the printing (of Trotter's book), 24 years old. But when I came across the name Jacob J. Sawyer, I knew nothing about him. ${ }^{3}$ What I could find in traditional academic databases and publications was very limited. He is now nearly forgotten, and only a very sketchy biography published in Eileen Southern's Biographical Dictionary of AfroAmerican and African Musicians (Southern, 1982, 332) reminds us of him. This dictionary entry did not even include the exact birth date or any information about his death. The entire entry reads as follows:

"SAWYER, JACOB. Composer (b. c1859 in Boston, Massachusetts [?]; fl. late nineteenth century). Little is known of his career except that he was highly regarded as a pianist-composer during his time. He toured with the Hyers Sisters Company as a pianist in 1878 and wrote songs especially for the company. A press notice in January 1884 referred to him as Boston's 'favorite Professor Jacob Sawyer' when he played on a local concert. Trotter includes one of Sawyer's pieces, 'Welcome to the Era March', in the 1878 survey. BIBL: Black press, incl. NYGlobe, 19 January 1884. Trot, p.2; 22-25 of the music section." (Southern, 1982, 332)

In addition to this dictionary article, John W. Finson mentioned Sawyer twice briefly in his book on The Voices That Are Gone (Finson, 1997). In his chapter on Postbellum Blackface Song: Authenticity and the Minstrel Demon, Finson writes:

"The heightened realism in the music of pseudo-spirituals and the increased attention to 'Negro oddities' for their own sake led to even more derogatory songs, as criticism of blacks gave way to deliberate malice. Jacob J. Sawyer admonishes the faithful in 'Blow, Gabriel, Blow' (1882):

Darkies pray fo' de time draws nigh,

Blow, Gabriel, Blow,

We'll soon be mountin' up on high,

Blow, etc.

2 Trotter included Sawyer's Welcome to the Era march on pp. 22-25 of the Music Appendix. However, Trotter does not mention Sawyer in the main text of his book.

3 I originally came across his name when I accepted the invitation to write an article about him for the latest edition of the Grove Dictionary of American Music (Schüler, 2013, 353). 
Chicken coops you mus' leave alone,

Blow, etc.

Or Satan 'll cotch you shu's you's bo'n, Blow, etc.

This advice is accompanied by a strictly pentatonic and highly syncopated tune $\left(\mathrm{Ex} .6 .10^{4}\right)$, which bears a distant resemblance to 'Gabriel's Trumpet's Going to Blow' as sung by Jennie Jackson of the Jubilee Singers. Presumably Sawyer employed his song in a major production number of the very famous and widely traveled Haverly's Colored Minstrels, whom he served as musical director." (Finson, 1997, 219-220)

It is not clear where Finson got the information, since no references to any Sawyer sources are given, but I assume that Finson's only sources were published scores, several of which identified Sawyer as the Musical Director of Haverly's Colored Minstrels or Musical Director, Haverly's Colored Minstrels on the title page underneath the composer's name. Later in the same chapter of his book, Finson mentioned Sawyer one more time:

\begin{abstract}
"Skits featuring black target companies enjoyed a vogue in many minstrel companies, and for one of the largest, Haverly's Colored Minstrels, Jacob J. Sawyer wrote 'I'm De Sargent Ob De Coonville Guards' (1881), 'Coonville Guards' (1881), and 'I'm de Captain ob the Black Cadets' (1881)." (Finson, $1997,225)$
\end{abstract}

While Finson must receive credit for mentioning Sawyer and for placing him into a history of minstrel songs, Eileen Southern provided biographical information on Sawyer as far as it was known when I came across the composer's name in 2011.

About 22 of Jacob J. Sawyer's compositions are listed in WorldCat, a handful of which are available in two to three libraries each and most of them only in one library each. However, the digital collection Music for the Nation: American Sheet Music, Ca. 1870 to 1885 by the Library of Congress in Washington, D.C., contains close to 50 of Sawyer's compositions, which have recently been scanned and are available online. Some of the scores contain information about the composer's affiliation with a particular performance ensemble, such as Sawyer's aforementioned position as "Musical Director of the Haverly's Colored Minstrels" in works published in 1881. These and other affiliations indicated in the publication of compositions by Sawyer are:

4 This example in Finson's book shows the beginning of the second stanza of Jacob J. Sawyer's

"Blow, Gabriel, Blow". 
1878-80 Pianist for the Hyers Sisters ${ }^{5}$

1881 Musical Director of the Haverly's Colored Minstrels ${ }^{6}$

1883 Pianist of the Slayton Ideal Company

1884-85 Musical Director of the Nashville Students

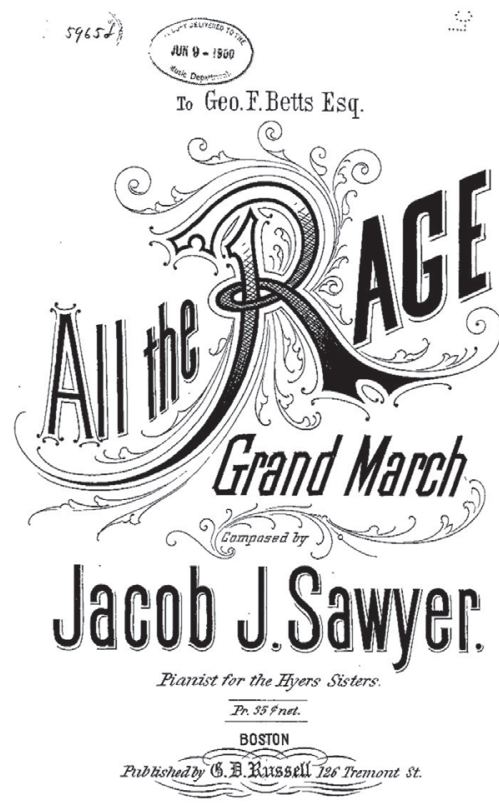

Figure 1: Title Page of Sawyer's All the Rage Grand March (Sawyer, 1880)7.

Since Sawyer turned 23 years old in 1879, and since he died in 1885 (as I later found out), it can be assumed that this list of affiliations is complete, or that these affiliations are at least his major affiliations. The Hyers Sisters were wellknown singers and pioneers of African-American musical theater (Southern, 1997, 244), while Haverly's Colored Minstrels was a successful black minstrelsy group owned and managed by Jack H. Haverly (1837-1901) (Toll, 1974, 146). The Slayton Ideal Company was a jubilee troupe by African-American actor and singer Sam Lucas (1840-1916). Finally, the financially successful and very popular Chicago-based Original Nashville Students was managed by the African-

\footnotetext{
5 See, for example, Figure 1.

6 See, for example, Figure 2.

7 This score is contained in the digital collection "Music for the Nation: American Sheet Music, Ca. 1870 to 1885 " in the Library of Congress in Washington, D.C.
} 
American H. B. Thearle; it toured nationally, performing vocal and instrumental music, dance, and comedy.

Numerous publications of Sawyer's music also contain dedications. Information on the individuals to whom his music had been dedicated is subject to further research.

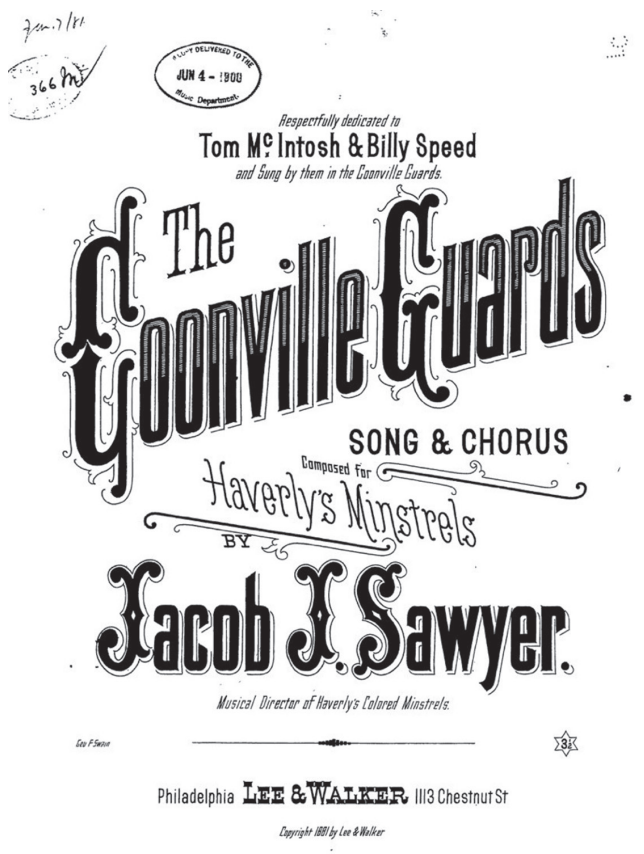

Figure 2: Title Page of Sawyer's The Coonville Guards (Sawyer, 1881). ${ }^{8}$

I found it intriguing that a composer whose compositions were widely published and even included by James M. Trotter would be largely forgotten. Not even his date of birth and date of death were known to Eileen Southern. To find more biographical information, I turned to the standard databases for research in music as well as in humanities in general - to no avail. I searched on the internet, which proved to be difficult, as "Jacob Sawyer" was a common name. I finally subscribed to several commercial genealogy and newspaper databases: www.genealogybank.com, www.ancestry.com, www.newspaperarchive.com, and www.newspapers.com. These large and rich commercial genealogy databases

8 This score is contained in the digital collection "Music for the Nation: American Sheet Music, Ca. 1870 to 1885 " in the Library of Congress in Washington, D.C. 
contained numerous documents about Sawyer. Searching in such databases is a task that requires much time and patience, as the vast majority of search results were either about other people named Jacob Sawyer, or the search results were faulty because "Jacob" may have appeared in one name and "Sawyer" in another on the same page of the document. In addition, not all documents are indexed correctly, as the optical text recognition may have been incorrect.

Most difficult was the initial search for the "correct" Jacob Sawyer, because Eileen Southern's information provided a relatively large (and incorrect) window for Sawyer's birth. The name Jacob Sawyer appeared in many census records, and I could only identify the correct Sawyer after weeks of going through many census records and many newspaper articles by noticing the name Ellen Sawyer in a newspaper article about the Nashville Students and Jacob Sawyer (New York Globe, 1884, 4. $)^{9}$, which I could then match to one of the census records that listed Ellen underneath Jacob's name as his sister. Thus, I could finally identify Sawyer in three census records $\left(1860,1870\right.$, and 1880). ${ }^{10}$ At this point, I had not yet found any information about Sawyer's death, nor the date of birth, and so I continued looking for documents on Sawyer beyond the 1880s, up until the mid- $20^{\text {th }}$ century, to no avail. By comparing the dates on which the census was conducted with Sawyer's age listed in the census records, the three census records enabled me at least to narrow his possible date of birth to between 30 July 1856 and 4 June 1857 . It was not until many months later that I could find the birth record (see Figure 3) on www.ancestry.com, listing his date of birth as 5 November, 1856. While Sawyer is listed in this birth record as "Jacob A. Sawyer", the middle initial must have been an error or possibly an abbreviation for a middle name later not used or changed; all other information in this record, including the names of Sawyer's parents, match with other records on the composer.

9 This is also the article that names Jacob Sawyer as "our favorite Prof Jacob J. Sawyer" that Eileen Southern mentions in her 1982 article.

${ }^{10}$ These census records were found via www.ancestry.com. 


\begin{tabular}{|c|c|c|c|c|c|c|c|}
\hline \multicolumn{2}{|c|}{$1850-1863$} & \multicolumn{6}{|c|}{ Births Registered in the TOWN of RoXbury. } \\
\hline 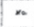 & sit & \multicolumn{2}{|c|}{ mentumas } & \multicolumn{2}{|c|}{$m \infty$} & $x=-x=-2$. & \multirow{2}{*}{ nonitu } \\
\hline & & 1096 & & & & & \\
\hline 520 & & Co 25 Mentersts & materes & , & 1. 702 & kerr & \\
\hline 521 & & $22 \operatorname{sen}$ & taxtos & , & - Somen 2 & ment & \\
\hline sez & & or 12 Jakn & syenen & x & X sasoph & kirr & \\
\hline 523 & & or 30 vilsen ? & costa & $x$ & 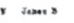 & arises & \\
\hline 524 & & 5 asese. & Bessoft. & $r$ & I Gonse & Sistuota & \\
\hline 525 & & 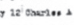 & sosts & * & - Sasta & woris & \\
\hline 526 & & N 31 nutenests & anseas & $x$ & - Etarerio. & narteres & \\
\hline 527 & & 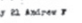 & $\sec x$ & a & × Bers & Detherisut & \\
\hline $5=0$ & $x_{y}$ & $y+20$ & sisterg (R)] & ix & 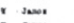 & Joens & \\
\hline 529 & & + Jas.. & Restery (So) ? & A & ; Jaser & soesenas & \\
\hline 500 & & Y) Morstio o & Mostans & $x$ & - 2und $x$ & Loor $x$ & \\
\hline 331 & & of 22 कs:-10, " & smaver & $x$ & r rreant. & Eatsertiog & \\
\hline 552 & & Wo N Merarest & soeteres & & - satria & 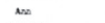 & \\
\hline 53 & & 49 Bour & nesor & r & - Lethosgy 9 & var, & \\
\hline $5 \%$ & & 53 sust. & Prastom & , & Pressiv & Rescubto of & \\
\hline 595 & & b) gee. I & mes & $x$ & - Joso & rannes & \\
\hline $5 \% 6$ & & $202 \mathrm{xens}$ & stome & , & I Obarist. & Jempense & \\
\hline 597 & & on besentr & mer & , & - Manos: & sor & \\
\hline 589 & & ins & tats & $x$ & 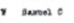 & avosise & \\
\hline 599 & & or 5 Jaseob $\bar{A}$ & suren & $\mathrm{x}$ & I rosos & nisubeth & \\
\hline 500 & & (1) $13 \mathrm{Am}$ & Esonem & $r$ & 1. Merresa & & \\
\hline
\end{tabular}

\begin{tabular}{|c|c|c|c|c|c|c|}
\hline tarert & Noxvern & nesteres: & insiene & Ireanes & & \\
\hline paristr & Sarbary & risombanger & $\because 2$ & Irotand & & 32 \\
\hline 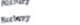 & Anstury & $\operatorname{cosisen}=\cos x$ & Martugnel & Irevens & 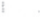 & 322 \\
\hline vistern & seriours & Sheor & theseres & $-x=$ & & 523 \\
\hline putar & nervory & suretior & $-x=$ & $\rightarrow \rightarrow$ & & $5=4$ \\
\hline ximg & 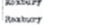 & 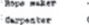 & atroung & nreasta & & \\
\hline meturr & sertarn & moner & somory & sostiend & & 507 \\
\hline $\operatorname{man} x$ & Rartury & conor. & 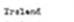 & imetence & & \\
\hline satory & nexpens & Lisorer & Ireatens & Ireinent & & 527 \\
\hline mabarn & sextoury & Fient & Derrtede & Mestarpors & & 930 \\
\hline Janowr & Mortury & Butoker & Goming & Gerengy & & $5 n$ \\
\hline sutorr & servarn & Lawerer & Fros Lne & Trosient & & 532 \\
\hline witery & neveren & Xerotiant & $\ldots x=$ & 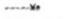 & & $m$ \\
\hline watos & maturn & Dustisener & Boston & semturnert & & $3 \%$ \\
\hline letsours & Rotsurr & Driskiaror & Eusand & zagient & & 35 \\
\hline intiver & nortury & mitanter & 200460 & resios & & 335 \\
\hline Imory & 3erkor & Wnoseostraser & Exateos & rextan & & 37 \\
\hline Nentury & soxturr & vatoher & Eastites" & $\ldots-w_{*}$ & & 398 \\
\hline betworg & Potart & Laboser & sorent & sooveses & & \\
\hline
\end{tabular}

Figure 3: Birth Register, Listing Jacob Sawyer Second-to-Last on this Excerpt. (Ancestry, 2011a) ${ }^{11}$

With the newly gained information indicating the exact date of birth, I could eventually also find the death record (Figure 4), listing the date of his passing as June 3,1885 , and identifying the cause of death as tuberculosis.
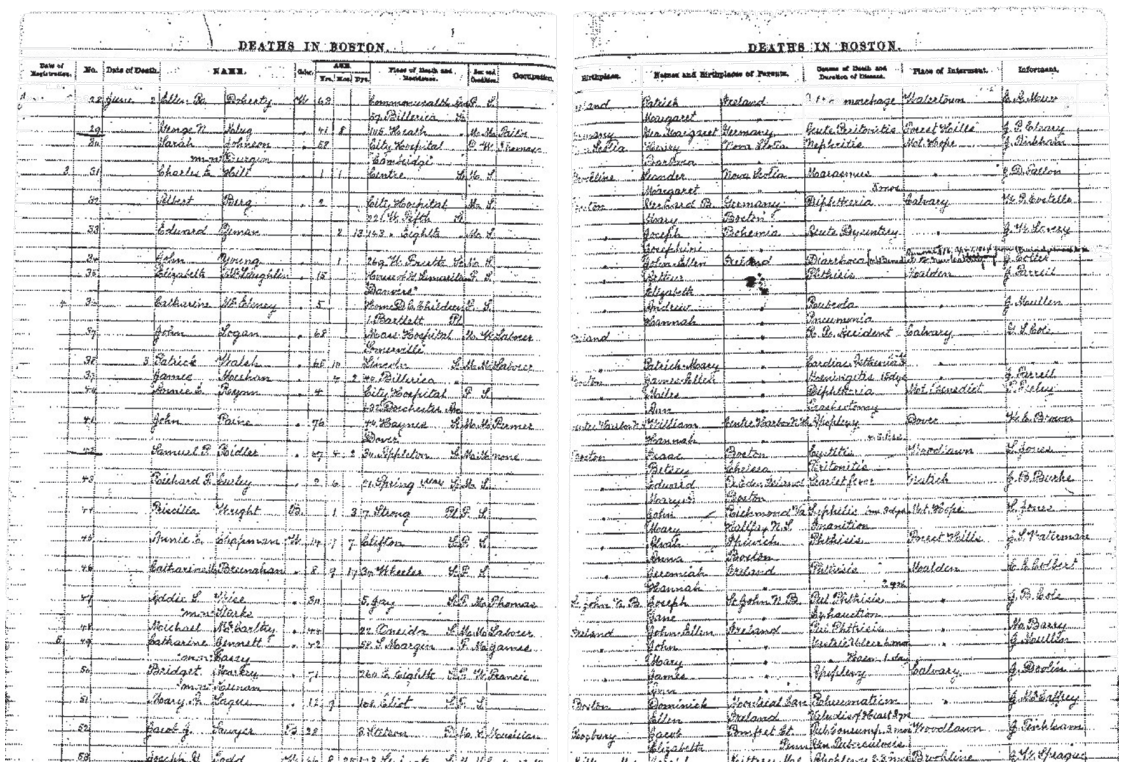

Figure 4: Death Register, Listing Jacob Sawyer Second-to-Last on this Excerpt. (Anon, 2013a) $)^{12}$

\footnotetext{
11 The original record can be found in Anon 2011b, 2011.

12 The original data can be found in Anon, 2013b.
} 
The first newspaper articles mentioning Jacob Sawyer are from Cincinnati in 1879, when he applied for a music teacher position. In the context of Sawyer's candidacy for the music teacher position, a misunderstanding by a reporter led to the publication of a local newspaper article in which Sawyer was mentioned as being a candidate for a college position; more specifically, Sawyer sent a letter ("card") to the newspaper to clarify that his candidacy was for a music teacher position, not for a college position (see Figure 4); because of this "card", we learn that Sawyer was examined and recommended for the music teacher position and that he was studying or taking lessons in music theory and violin at the Cincinnati College of Music at that time (at which Theodore Thomas was the director from 1878 to 1879 ). The Education Board meeting notes were regularly published, so that the newspapers reported about Sawyer's candidacy for the music teacher position and that he was ultimately not chosen.

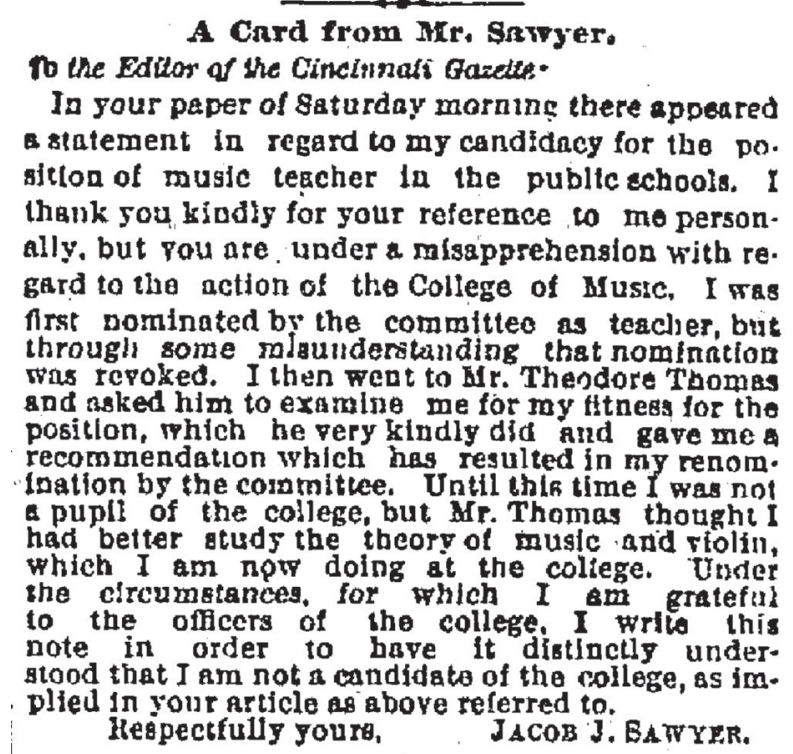

Figure 5: Sawyer Letter to the Cincinnati Daily Gazette (Cincinnati Daily Gazette, 1879).

Interestingly, one of the other applicants for the teacher position had bribed a Board member, which caused an investigation, about which, in turn, was reported in the newspaper. As part of the investigation, all applicants, including Sawyer, were questioned, and thus mentioned in articles reporting on the investigation.

Other newspaper articles reported on the publication of new music, and other newspaper articles reported about performances by Sawyer. 
While his early death from tuberculosis led his legacy to sink into oblivion, it was with the help of online genealogy and music score databases that some of his biography could be reconstructed. While not long, the following biography contains much more information than E. Southern's entry in her biographical dictionary mentioned earlier ${ }^{13}$ :

Pianist, composer, teacher, and arranger Jacob J. Sawyer (Jacob J. A. Sawyer) was born on November 5, 1856, in Boston, Massachusetts. He was the son of Jacob and Elizabeth Sawyer. From at least 1878 through 1880, he was the pianist for the Hyers Sisters Troupe, which brought him to Cincinnati, Ohio, no later than mid-1879. There, he took lessons in music theory and in violin at the College of Music of Cincinnati. He also composed the Seventh Exposition Grand March for piano (1879) for the Seventh Cincinnati Industrial Exhibition in 1879. He applied for a music teacher position in Cincinnati, but was not chosen. Sawyer returned to his home in Boston, where the 1880 census lists him as "Laborer." An African American composer, he wrote songs for the Haverly's Colored Minstrels, of which he was the Musical Director at least in 1881. A series of his compositions published in 1883 lists him as the pianist for the Slayton Ideal Company. Several documents from 1884 and 1885 name Sawyer as the Musical Director of the Nashville Students. All of Sawyer's known professional engagements resulted in extensive touring as well as in compositions specifically written for those ensembles. His work comprises numerous vocal compositions with piano accompaniment as well as dances for solo piano. James M. Trotter reprinted one of Sawyer's marches in his 1880 book Music and Some Highly Musical People. Sawyer died from tuberculosis at age 28 on June 3,1885 , in Boston.

\section{The Myth of Edmond Dédé's Lost Violin}

Music-historical research has its limits when it comes to detailed biographical information of composers who lived before the information age. Much information has been lost, and some information has been distorted. One such example of distorted biographical information is the myth about the lost violin of African-American violinist and composer Edmond Dédé (1827-1901). There may be numerous aspects of Dédés biography that need attention, but this section focuses on the "lost violin myth", which continues to be spread even in most recent scholarly research on Dédé. To provide context, this section will start with a short biography, followed by a discussion of the origin of the lost violin myth. At the center of this discussion are newspaper articles - found in online archival research - which show that Dédés violin was, in fact, never lost. ${ }^{14}$

\footnotetext{
${ }^{13}$ An earlier version of this brief biography was first published as part of Schüler, 2013.

${ }^{14}$ I discovered most of the newspaper articles on Dédé quoted later in this article in the Fall
} 
Edmond Dédé was born on November 20, 1827, in New Orleans. He was a free-born African-American whose family roots go back to the French West Indies. Edmond first learned clarinet, probably from his father, then violin. Many sources call him a prodigy on the violin. Among his teachers was the French composer Eugene Prévost, who was the conductor at the French Opera in New Orleans between 1838 and 1862. After years of musical education in his native New Orleans, he lived in Mexico in the late 1840s and very early 1850s (from 1848 to 1851 , according to Sullivan, 1988, 54). After his return to New Orleans, he mainly worked as a cigar maker, in addition to performing and composing, to save money for a passage to Europe. He left for Paris in 1857. According to all published biographical sketches, Dédé studied at the Paris Conservatoire, after which - in about 1860 - he moved to Bordeaux to work for several orchestras. He married Sylvia Leflet in 1864, and they had a son who also became a composer: Eugène Arcade Dédé (1867 - 1919). Edmond Dédé went to New Orleans from late-1893 to mid-1894 to visit family and concertize. He spent the last years of his life in Paris, where he died in 1901 (the exact date is unknown). Among Dédé's compositions are divertissements, overtures, dances, songs, an opera, and chamber music.

Although some of the biographical details have yet to be confirmed and may be exaggerations, the following newspaper article provides a glimpse at the nevertheless great achievements of a black musician born in the American south before the Civil War. The article was published on page 9 of The Times-Democrat in New Orleans, Louisiana, on Monday, December 11, 1893, which is shortly after Dédé's arrival in New Orleans:

\section{“PROF. DÉDÉ'S BENEFIT}

\section{Pleasant Musical Entertainment Last Evening.}

The Friends of Hope Hall, on Treme street, was filled to overflowing last evening with those who had gathered to attend the vocal and instrumental concert given for the benefit of Prof. Edmond Dédé. Every seat was occupied and the aisles and sides were packed by those standing.

of 2010 via Ancestry.com, Genealogybank.com, and Newspapers.com, after discussions with Christopher T. F. Hanson, who sparked my interest in Edmond Dédé as well as my skepticism in much of the published Dédé scholarship. (Hanson, 2011) An even greater spark - in both, interest and critical view of the literature - came from Sally McKee in an e-mail exchange in January of 2011, whom I had asked for information about Dédé's wife, Anne Catherine Antoinette Sylvia Leflet. Professor McKee graciously shared several of the biographical inconsistencies regarding Dédé in prior published research, including the lost violin myth. I would very much like to thank her for sharing some of her findings of her very extensive Dédé research, and I look forward to reading her forthcoming book The Exile's Song: Edmond Dédé and the Unfinished Revolution of the Atlantic World. (in press). New Haven: Yale University Press, 2017. (McKee, 2011) 
Prof. Dédé was a passenger of the ill-fated steamer Marseille which was lost a short time ago, since which he has been visiting relatives at Galveston, Tex. He arrived in this city a few days ago and his friends made arrangements for a complimentary concert to be given him, the entertainment taking place last evening.

Prof. Dédé is a native of this city, being born here in 1827. He went to Mexico in 1848 , but soon after proceeded to England, from whence he eventually took up his permanent residence in Paris, where he soon became well known and noted in musical circles. Having a natural aptitude for stringed instruments, he devoted his time to the violin, and soon reached a degree of proficiency that called attention to him.

Entering the Conservatory of Music, he became a pupil successively of Profs. Halévy and Alard, receiving from them the full benefits of their experience and knowledge. Upon leaving the Conservatory he carried with him several medals of the institution.

The professor became at once composer, chief violinist and orchestral conductor. For many years he most acceptably filled the latter position at the Grand Concert Parisian, one of the best known musical resorts in Paris. As chief violinist Prof. Dédé has traveled extensively over Europe with different orchestral organizations.

The most noted of the compositions coming from the professor are the "Abies," "Les Faux Mandarins," "La Sensitive" and the "Diane nea Aeteon," all of which were published in Paris, and being ballet music were at once adopted by many of the leading theatres. He is at present engaged in composing a four-act opera to be called the "Sultan D'Ispahan," and considers that it will eclipse all his previous efforts.

It is the professor's idea that no man is master of the violin until, as he quaintly expresses it, the instrument can be made "to talk and sing." His renditions last evening showed him to be a fine musician. While the theme was never lost sight of, the marvelous variations and wonderful execution were sufficient to show him to be classical, but it is not in classic music that he excels. In the sweet, low, dreamy notes of exquisite melody his subtle power came forth, and in them his full ability was shown. It was in them that the violin sang. His "Faust" was particularly fine, and the "Reverie" was superb.

Agnes Desdunes is a pleasing violinist, and her selections were well given, meeting with deserved applause. Basile Bares was perfectly at home at the piano, and the others were nicely received in their various renditions.

Prof. Dédé expects to return to Paris before May to take an engagement at the Theatre Quinquonces." (The Times Democrat, 1893)

The myth of the "lost violin" goes back to this 1893 visit in New Orleans, Dédé's last visit in the United States. For the passage from Bordeaux to New Orleans, he took the steamship Marseille, which was disabled by a water leak during a storm in 
October 1893. Most of the 47 passengers were rescued (by the English tramp ship Palmos), including Dédé, the only first-class ("Cabin") passenger, but his beloved and very valuable Cremona violin was supposedly lost. We can find mentions of the "lost violin" in numerous publications, including this press release written on October 19, 1893, published on page 7 in The Austin Weekly Statesman (Austin, Texas) on Thursday, October 26, 1893, shortly after the rescue:

"Other scenes displaying bravery and presence of mind were enacted during the landing of the passengers on the Palmos. On board the Marseilles was Edmond Dede, a negro composer of some note, who lost a costly violin and all his belongings. He was on his way to New Orleans, his home, after an absence of 39 years." (The Austin Weekly Statesman, 1893)

Since then, the story of the "lost violin" has been repeated time after time, without citing any source on this particular piece of information, and can be found on today's websites about the composer:

"During his journey to the United States, he lost his precious Cremona violin. Forced to use a different instrument, he still performed to accolades." (Wikipedia, 2016.)

"The ship on which Dede had booked passage from France to New Orleans had such a rough crossing that the vessel was compelled to seek port on the Texas coast. During the experience Dede lost his favorite violin, a Cremona. This misfortune, however, did not prevent his appearance in New Orleans often in concert halls with poor acoustics - where he captivated his audiences even with a borrowed instrument greatly inferior to his lost Cremona." (French Creoles of America, 2016.)

"Edmund Dédé returned to New Orleans only once, in 1893. He came ashore in Texas after the wreck of the steamer Marseille, The Houston Daily Post wrote on Oct. 22, 1893. Dédé lost his treasured Cremona violin at sea when shipwrecked en route to the United States, but his performances on another instrument were praised by critics and audiences alike." (African Heritage in Classical Music, 2016.)

Early discourses on African-American musicians adopted the myth, too. For example, Rudolphe Lucien Desdunes wrote in his book Our People and Our History, originally published in French in 1911 as Nos Hommes et Notre Histoire:

"The ship on which Dédé had booked passage from France to New Orleans had such a rough crossing that the vessel was compelled to seek port on the Texas coast. During this experience Dédé lost his favorite violin, a Cremona. This 
misfortune, however did not prevent his appearance in New Orleans-often in concert halls with poor acoustics - where he captivated his audiences even with a borrowed instrument greatly inferior to his lost Cremona." (Desdunes, $1973,86)$

In her book Negro Musicians and Their Music from 1936, Maud Cuney-Hare wrote in a footnote: "Dédé was the owner of a valuable Cremona violin which was lost when he was shipwrecked." (Cuney-Hare, 1936, 238) The story about the "lost violin" can even be found in most modern scholarly publications on Dédé, for example: "He was on his way home to visit relatives when, during a rough crossing, the ship on which he was traveling was disabled. In the confusion, his Cremona violin was lost." (Sullivan, 1988, 57), or "On the journey to America, Dédé's ship was caught in a violent storm and his treasured Cremona violin was lost at sea." (Hanson, 2011, 7)

Searching more extensively in the commercial genealogy and newspaper databases, I found numerous articles that debunk the myth of the "lost violin". Several newspaper articles of the time, based on first-hand accounts by the passengers, covered the disabled steamship and the rescue of its passengers, many of which state that Dédé lost everything except his violin. For example, the Dallas Morning News printed the following article - written on October 22 - on Monday, October 23, 1893:

\section{“EDMOND DEDE}

\section{A Man Whose Life Has Been Remarkable Rescued from the Gulf.}

Galveston, Tex., Oct. 22.-Among the passengers rescued from the foundered Marseille set ashore in this port by the Palmas, the only cabin passenger was Edmond Dede of Paris, France. Mr. Dede is a remarkable man. He is a fullblooded negro, born in the city of New Orleans in 1827, free born. He left his native city nearly forty years ago and has since made his home in Paris and Bordeaux. It is not his place of birth or French residence which stamps him as a remarkable man, but the fact that since his residence in France he has become one of the leading musicians of that republic. His business card introduces him as a composer of music and a chief of the orchestra of the Grand theater of Bordeaux, a member of the society of authors and editors of music, and a member of the society of authors and composers of dramatic music. Mr. Dede fortunately succeeded in saving his valuable violin, which is an Amati, purchased in France for 2000 francs." (Dallas Morning News, 1893) 
The Galveston Daily News (published in Galveston, Texas) published an article on Monday, October 23, 1893, that contains the following passage:

"Mrs. Erado says it is the intention of herself and her friends to got up a benefit for Mons. Dede, when the public will have an opportunity to listen to a master of the violin. Mons. Dede succeeded fortunately in saving his valuable violin, which is an Amati, purchased in France for 2000 francs." (The Galveston Daily News, 1893)

The Brooklyn Daily Eagle (published in Brooklyn, New York) wrote on page 8 on Sunday, November 5, 1893: "Edmond Dede, who got ashore from the wrecked steamer Marseille at Galveston, with only his violin, is a full blooded negro. His musical works, including operas, number over two hundred." (The Brooklyn Daily Eagle, 1893)

Other articles make no mention of the violin at all, such as a longer article on page 6 of The Times-Picayune, published in New Orleans, Louisiana, on Saturday, October 21, 1893, which contains the following two paragraphs about Edmond Dédé:
"The only colored passenger aboard the Marseille at the time of the disaster was Edmond Dede. He was saved and reached the city yesterday morning via the Southern Pacific Road. An attempt to locate him last evening, to obtain an account of his experiences, proved futile. He has a number of relatives here who reside in the Second district, but none had seen him since his arrival. They were all visited. Some had not heard of his coming, but a brother-in-law, residing on St. Ann, between Robertson and Claiborne streets, had received a letter from him posted at Galveston, announcing that he would reach here to-day. This brother-in-law is a steamboatman, and was compelled to be away from the city, which obviated his being able to meet Dede at the depot.
Dede was born in this city about 62 years ago, and resided in the French quarter. He left here some thirty-seven years ago, going to Paris, France, where he has ever since lived. His present visit was merely to visit his relatives here, it being his intention to return to France shortly, where his wife and son now are." (The Times-Picayune, 1893)

Even the concert reviews make no mention of the violin. If the violin had indeed been lost at sea, then the violin would have been a central part of the benefit concerts for Dédé. The only mention of the "lost violin" in a daily newspaper immediately after the ship disaster was the article written on October 19, 1893, published in The Austin Weekly Statesman quoted above. The article was written the same day as the survivors arrived in Galveston. (The Austin Weekly Statesman, 1893) The circumstances of that article cannot be reconstructed, 
but one can assume that the situation was still chaotic. All later articles make no mention of the "lost violin". One may speculate that later authors may have had access to this first article, published in the capitol of Texas, Austin, but not to other newspapers from Galveston and/or New Orleans. But because the explicit statements in those latter newspapers that everything except the violin was lost and because of the lack of mentioning a "lost violin" in the benefit concert reviews, one must assume that the violin was, in fact, never lost.

\section{Final Remarks}

Commercial genealogy databases as well as digitized (online) collections of music scores were the main sources for rediscovering and reconstructing the biography of Jacob J. Sawyer and for clarifying some aspects of Edmond Dédés life. While neither research project is complete, the main biographical facts and the composer's affiliations with important musical ensembles have been uncovered. Future research may continue searching for literature and documents on the well-known musicians with whom Sawyer as well as Dédé were associated, in the case of Sawyer such musicians as The Hyers Sisters, Sam Lucas, The Haverly's Colored Minstrels, and The Nashville Students. While documents may still be found in archives or antiquarian music stores, online commercial genealogy and newspaper databases will continue to be important sources for the rediscovery of both composers.

\section{References}

African Heritage in Classical Music, 2016. Edmund Dédé (1827-1903): African American Composer, Violinist \& Conductor: A Creole Romantic in Exile. [online] Available at: http://chevalierdesaintgeorges.homestead.com/Dede. html. [Accessed 5 April 2016].

Anon, 2011a. Massachusetts, Town and Vital Records, 1620-1988. [database online] Available at Ancestry.com database: https://search.ancestry.com/ search/db.aspx?dbid=2495. [Accessed 5 April 2016].

Anon, 2011b. Massachusetts Vital and Town Records. [database with images] Town and City Clerks of Massachusetts. Provo, UT: Holbrook Research Institute [Jay and Delene Holbrook].

Anon, 2013a. Massachusetts, Death Records, 1841-1915 [database online] Available at Ancestry.com database at: https://search.ancestry.com/search/ db.aspx?dbid=2101. [Accessed 5 April 2016]

Anon, 2013b. Massachusetts Vital Records, 1840-1911. [database with images] Boston, Massachusetts: New England Historic Genealogical Society. 
Cincinnati Daily Gazette, 1879. A Card from Mr. Sawyer. Cincinnati Daily Gazette, 20 Aug, p. 6. Available at: Genealogy Bank website http://genealogybank. com. [Accessed 2 November 2016].

Cuney-Hare, M., 1936. Negro Musicians and Their Music. Washington, DC: Associated Publishers.

Dallas Morning News, 1893. Edmond Dede. A man whose life has been remarkable rescued from the gulf. Dallas Morning News, 22 Oct, p. 3.

Desdunes, R. L., 1973. Our People and Our History. Translated and edited by D. O. McCants. Baton Rouge: Louisiana State University Press.

Finson, J. W., 1997. Voices That Are Gone: Themes in Nineteenth-Century American Popular Song. Cary, NC: Oxford University Press.

French Creoles of America, 2016. Edmond Dede: World Famous Black Creole musician/composer. [online] Available at: http://www.frenchcreoles.com/ MusicEvents/edmonddede/edmonddede.htm. [Accessed 5 April 2016].

Hanson, C. T. F., 2011. An Analytical View of Edmond Dédés Mephisto Masque Polka Fantastique: An Argument for Recognition. Master Thesis. Texas State University.

McKee, S., 2011. Discussion about Edmond Dédés life. [e mail] (Personal communication, January 2011)

New York Globe. 1884. Our Hub Letter. New York Globe, 19 Jan. p. 4. Available through: Genealogy Bank website http:// genealogybank.com [Accessed on 2 November 2016].

Sawyer. J. J., 1880. All the Rage. Grand March. [score] Boston: G. D. Russell. Sawyer, J. J., 1881. The Coonville Guards. [score] Philadelphia: Lee \& Walker. Schüler, N., 2013. Sawyer, Jacob J. In: C. H. Garrett, ed. The Grove Dictionary of American Music. 2nd edition. Vol. 7. New York: Oxford University Press.

Schüler, N., 2015. Rediscovering Forgotten Composers with the Help of Online Genealogy and Music Score Databases: A Case Study on African-American Composer Jacob J. Sawyer (1856-1885). Musicological Annual, 51(2), 85-97. Schüler, N., 2016. The Myth of Edmond Dédés Lost Violin. South Central Music Bulletin, XIV (1-2), 32-35.

Southern, E., 1982. Biographical Dictionary of Afro-American and African Musicians. Westport, CT: Greenwood Press.

Southern, E., 1997. The Music of Black Americans: A History. $3^{\text {rd }}$ edition. New York: W. W. Norton.

Sullivan, L., 1988. Composers of Color of Nineteenth-Century New Orleans: The History behind the Music. Reprint 2000. In: S. Kein, ed. The History and Legacy of Louisiana's Free People of Color. Baton Rouge, LA: Louisiana State University Press. 71-100.

The Austin Weekly Democratic Statesman, 1893. Story of the Week. The Austin Weekly Statesman, 26 Oct. p. 8. 
The Brooklyn Daily Eagle, 1893. Notes. The Brooklyn Daily Eagle, 5 Nov. p. 8.

The Galveston Daily News, 1893. Mons. Dede, Composer. The Galveston Daily News, 23 Oct. p. 8.

The Times-Democrat, 1893. Prof. Dédés benefit. Pleasant musical entertainment Last Evening. The Times-Democrat, 11 Dec. p. 9.

The Times-Picayune, 1893. Rescued from the La Marseille. The Times-Picayune, 21 Oct. p. 6.

Toll, R. C., 1974. Blacking Up: The Minstrel Show in Nineteenth-Century America. New York: Oxford University Press.

Trotter, J. M., 1880. Music and Some Highly Musical People. Boston, MA: Lee \& Shepard.

Wikipedia, 2016. Edmond Dédé. [online] Available at: https://en.wikipedia.org/ wiki/Edmond_Dédé. [Accessed 5 April 2016]. 